\title{
Environmental Attitudes of Macedonian School Students in the Period 1995-2016
}

Summary: The main purpose of this study is to analyze the environmental attitudes in the population of Macedonian school students in the last 22 years. This review was conducted through five basic steps: framing questions for the review, identifying relevant work, assessing the quality of studies, summarizing the evidence, and interpreting the findings. Three different instruments have been used to collect the data over the period under review. In the period 1995-2016, a sample of 6387 students from both primary and secondary schools was included. Most of the participants reported pro-environmental attitudes (3.50 or 70\%). Among the factors that influence students' attitudes towards the environment in Macedonian context are understanding, social safety, socio-economic status, and formal education (curricula, didactic materials- textbooks, environmental knowledge, and teaching process). Since people's environmental attitudes change very slowly, environmental attitudes should be created in the young minds of pupils during the earlier years of education, and as soon as possible. The results of this review may help to explain the situation and describe the obstacles and possibilities for environmental education in the schools of the Republic of North Macedonia.

Keywords: attitudes, school students, Republic of North Macedonia, factors.

\section{Introduction}

The environment has long been a topic of global interest. The global nature of environmental problems does not respect international borders and has become a widespread matter of concern among the general public. "Two tendencies can be linked to this phenomenon. Firstly, there is an ever-greater need for a global response to global problems. This is already underway in numerous international environmental agreements and legislation. Secondly, citizens are becoming more aware of both the potential effects of these problems in their daily lives and the role they could play in protecting their environment" (European Commission, 2008: 3). From

1 m.srbinovski@seeu.edu.mk Copyright $\odot 2019$ by the authors, licensee Teacher Education Faculty University of Belgrade, SERBIA.

This is an open access article distributed under the terms of the Creative Commons Attribution License (CC BY 4.0) (https://creativecommons.org/licenses/by/4.0/), which permits unrestricted use, distribution, and reproduction in any medium, provided the original paper is accurately cited. 
that, the most Europeans take action to protect the environment (European Commission, 2014).

Education and training play a crucial role in helping individuals and societies to adapt to profound social, economic and cultural changes, and foster the development of the human capital needed for economic growth (Organization for Economic Co-operation and Development-OECD and The United Nations Educational, Scientific and Cultural Organization-UNESCO (2001)). Based on the qualitative and quantitative analysis of 36 documents related to environmental education, Srbinovski (2004b: 26) defined the term environmental education in the following way: 'environmental education is a developing process of active learning in which individuals and groups acquire the necessary knowledge, understanding, attitudes and skills for a determined, motivated, responsible, and, above all, joint action towards obtaining and maintaining a dynamic balance in the environment'. Schools as one of the social systems responsible for the development of citizenry should be charged with developing cognitive, psychomotor, and affective skills to equip students with the ability to make environmentally responsible decisions. The cognitive domain deals with remembering or understanding of concepts, ideas, and facts. The psychomotor variable involves skills in carrying out physical and mentally co-ordinate activities. The affective variable involves feelings or emotions, attitudes and values towards objects. Iozzi A. (1989) points out that the cognitive and affective domains function cooperatively.

Attitudes and values reflect feelings of concern for the environment. Attitudes are mental states based on personal beliefs towards pollution, fragility, interdependence and equal importance of all life forms, dependence of human life on the resources of a finite planet, power of human beings to modify the environment, conservation, environmental action, etc. A belief is acceptance of something as a fact whether supported by evidence or not. Environmental attitudes have been defined as "the collection of beliefs, affect, and behavioral intentions a person holds regarding environmentally related activities or issues" (Schultz et al., 2004: 31). New theoretical approaches prefer to conceptualize attitudes as evaluative tendencies that can both be inferred from and have an influence on beliefs, affect, and behavior (Milfont \& Duckitt, 2010).

Measuring adolescent environmental perception is a multifaceted task. There are many scales to measure environmental attitudes and concern. A widely used measure of environmental worldview is Dunlap and Van Liere's New Environmental Paradigm (NEP) Scale, first published in 1978. The scale was revised by Dunlap et al. (2000), and became the New Ecological Paradigm Scale (Dunlap et al., 2000: 433). This scale is the first psychometrically and conceptually sophisticated instrument to assess pro-environmental worldviews. It proposes the environmental attitudes view as a unidimensional construct. Schultz (2001) proposed three correlated factors of egoistic, altruistic, and biospheric concerns. Wiseman and Bogner (2003) developed the Model of Ecological Values (2-MEV) with two orthogonal dimensions, preservation and utilization. Johnson and Manoli (2011) propose a Revised 2-MEV scale for use with 9-12-year-old children. The 2-MEV treats biocentrism and anthropocentrism as two separate and not necessarily related components. On the other hand, on the NEP scale, an individual can either have a pro-environmental or an anti-environmental perspective, but not both. While the NEP scale can be useful in some studies, particularly those looking at groups with extreme environmental perceptions, the 2-MEV scale's ability to provide a more complete picture of people's environmental perceptions calls for its broader use (Manoli et al., 2019). The Revised 2-MEV Scale is able to measure statistically significant changes in the environmental attitudes of participants in earth education programs but not in a control group. This scale can be used to evaluate programs and to investigate the relationship between environmental attitudes and other variables. It also formed the basis 
for the Theory of Ecological Attitudes (Bruce and Manoli, 2011). The 2-MEV Scale was modified for use with 9-12-year-old children in the United States by the same authors. Adaptation was done by revisions and elimination of some items. Confirmatory Factor Analyses indicated that the remaining items fit the Theory of Ecological Attitude well. However, the dimensionality of environmental attitudes and the nature of the dimensions are still being discussed (e.g. Srbinovski, 2016).

The Republic of North Macedonia, as a candidate country for a member state of the European Union, goes through a transitional period trying to solve important environmental problems and issues caused by this process. At the same time, being part of the European Union sets high ecological standards that North Macedonian institutions have to meet. On the other hand, during this period people have become more self-centered and focused on satisfying their basic needs. Therefore, environmental problems and issues become less important to them.

There are two great reasons for increasing the environmental quality in the Republic of North Macedonia: (i) our country faces major challenges in the field of environmental protection and improvement, especially in terms of air pollution (e.g. some North Macedonian cities are among the most air polluted cities in the World), and (ii) as an aspirant country in the European Union, North Macedonian institutions have an obligation to meet the EU criteria in this field.

In this situation, it is important to develop awareness and positive attitudes towards the environment, as predictors of eco-friendly behaviour. Developing both students' knowledge and awareness of environmental issues has never been such an important goal of science education as now. But this teaching must be based on the knowledge of students' attitudes towards the issue of environmental protection (Sjoberg and Schreiner \&, 2005). Understanding environmental attitudes is important because they often, but not always, determine behav- ior that either increases or decreases environmental quality. For example, a meta-analysis of studies in the area of responsible environmental behavior (Hines et al., 1986/87) found the attitudes toward environment to be strongly associated with behavior $(r=.347)$. Srbinovski M. (2005b) reported similar result in Macedonian context $(r=.275)$. In addition, some researchers have argued that the most important determinant of behavior is attitude (Eagles \& Demare, 1999; Kraus, 1995).

The main purpose of this study is to analyze the environmental attitudes in the population of Macedonian students in the past 22-year period. The tasks of examination are: (i) to investigate the students' level of the environmental attitudes in the period 1995-2016, and (II) to identify the factors influencing students' environmental attitudes in Macedonian context. The work hypotheses are: (i) we assume that most of the participants have proenvironmental attitudes and, (ii) we assume that there is a "link" between students' attitudes towards the environment and socio-demographic conditions in the Republic of North Macedonia.

\section{Materials and methods of the research}

The first step in conducting this research was to create a specified in the form of clear, unambiguous and structured question to guide the review. The second one was to perform a thorough search of the literature for relevant papers (both computerized and printed) without language restrictions. The third step was assessing the quality of studies. The next one was summarizing the evidence or data synthesis. This step consists of tabulation of study characteristics, and results, as well as the use of statistical methods for exploring differences between studies. The fifth step involved interpreting the findings. Data analysis was conducted both in the context of socialeconomic conditions and formal education in the Republic of North Macedonia. 
Attitudes as affective dispositions toward the environment are the subject of this research. Three different instruments have been used to collect data over the period under review (Table 1): Scale of attitudes -SA-3 (Kundačina, 1991), Scale of attitudesSA-6 (Srbinovski, 2001), and New Ecological Paradigm Scale- NEP scale (Dunlap et al., 2000). Both SA-3 and SA-6 were constructed as parts of doctoral theses by Kundačina, M. (1991), and Srbinovksi, M. (2001), respectively. SA-3 with 13 items was used in the period 1995/96-1997/98. In the SA-3 respondents have been asked to consider whether the environment is important to them and future generations. They have been also asked to state their attitudes about the link between environmental quality and the development of society, the ways of protecting the environment, etc. The examples of scale items are: "We cannot preserve nature by laws and appeals, but by specific actions", and "Preserving the environment is more than necessary for the lives of future generations"). SA-6 was used in the period 1999/2000-2011/12. This scale consisted of 13 items.
In the SA-6 scale also is included range of factors (e.g. pollution, fragility, interdependence and equal importance of all life forms, dependence of human life on the resources of a finite planet, power of human beings to modify the environment, conservation, etc.). The examples of scale items are: "By protecting the nature, we protect ourselves and future generations', and "People are the most responsible factor for environment protection". In the last sub-period (2015-2016), we used NEP scale with 15 items. In contrast to the "dominant social paradigm" (DSP), which views humans as separate from, and superior to nature, the NEP perceives environmental concern as endorsement of a new ecological worldview where humans are a part of nature (Burn et al., 2012: 137). The examples of scale items are: "When humans disturb or interfere with nature, it often produces disastrous consequences", "Plants and animals have as much right as humans to exist", "The balance of nature is very delicate and easily upset", and "If things continue on their present course, we will soon experience a major ecological

Table 1. Scales to measure environmental attitudes, author/s, items and users, by years.

\begin{tabular}{|c|c|c|c|c|c|c|c|}
\hline & $\mathbf{1 9 9 5 / 9 6}$ & $\mathbf{1 9 9 7 / 9 8}$ & $\mathbf{1 9 9 9 / 0 0}$ & $\mathbf{2 0 0 1 / 0 2}$ & $\mathbf{2 0 0 8 / 0 9}$ & $\mathbf{2 0 1 1 / 1 2}$ & $\mathbf{2 0 1 5 / 1 6}$ \\
\hline Scale & $\begin{array}{c}\text { Scale of } \\
\text { attitudes } \\
\text { (SA-3) }\end{array}$ & $\begin{array}{c}\text { Scale of } \\
\text { attitudes } \\
(\text { SA-3) }\end{array}$ & $\begin{array}{c}\text { Scale of } \\
\text { attitudes } \\
\text { (SA-6) }\end{array}$ & $\begin{array}{c}\text { Scale of } \\
\text { attitudes } \\
(\text { SA-6) }\end{array}$ & $\begin{array}{c}\text { Scale of } \\
\text { attitudes } \\
\text { (SA-6) }\end{array}$ & $\begin{array}{c}\text { Scale of } \\
\text { attitudes } \\
\text { (SA-6) }\end{array}$ & $\begin{array}{c}\text { New Ecological } \\
\text { Paradigm Scale- } \\
\text { NEP scale }\end{array}$ \\
\hline $\begin{array}{c}\text { Author/s, } \\
\text { year }\end{array}$ & $\begin{array}{c}\text { Kundacina, } \\
\text { Items }\end{array}$ & $\begin{array}{c}\text { Kundacina, } \\
1991\end{array}$ & $\begin{array}{c}\text { Srbinovski, } \\
2001\end{array}$ & $\begin{array}{c}\text { Srbinovski, } \\
2001\end{array}$ & $\begin{array}{c}\text { Srbinovski, } \\
2001\end{array}$ & $\begin{array}{c}\text { Srbinovski, } \\
2001\end{array}$ & $\begin{array}{c}\text { Dunlap et al., } \\
2000\end{array}$ \\
\hline Used by & $\begin{array}{c}\text { Srbinovski, } \\
1995 / 96\end{array}$ & $\begin{array}{c}\text { Srbinovski, } \\
1997 / 98\end{array}$ & $\begin{array}{c}\text { Srbinovski, } \\
2001\end{array}$ & $\begin{array}{c}\text { Srbinovski, } \\
2001 / 02\end{array}$ & $\begin{array}{c}\text { Jonuzi, } \\
2008 / 09\end{array}$ & $\begin{array}{c}\text { Jonuzi, } \\
2012, \text { Idrizi } \\
\text { et al., 2014 }\end{array}$ & $\begin{array}{c}\text { Srbinovski, } \\
2016\end{array}$ \\
\hline
\end{tabular}

Table 2. Schools and students included in the research, by years.

\begin{tabular}{|c|l|c|c|c|c|c|c|c|}
\hline \multicolumn{2}{|c|}{ YEAR } & $1995 / 96$ & $1997 / 98$ & $1999 / 00$ & $2001 / 02$ & $2008 / 09$ & $2011 / 12$ & $2015 / 16$ \\
\hline \multirow{3}{*}{ Schools } & Elementary & 9 & 9 & 19 & 6 & 0 & 0 & 3 \\
\cline { 2 - 9 } & Secondary & 8 & 8 & 19 & 8 & 19 & 19 & 5 \\
\cline { 2 - 9 } & Total & 17 & 17 & 38 & 14 & 19 & 19 & 8 \\
\hline \multirow{3}{*}{ Students } & Elementary & 556 & 1010 & 515 & 290 & 00 & 00 & 139 \\
\cline { 2 - 9 } & Secondary & 651 & 1047 & 488 & 414 & 484 & 484 & 309 \\
\cline { 2 - 9 } & Total & 1207 & 2057 & 1003 & 704 & 484 & 484 & 448 \\
\hline
\end{tabular}


catastrophe. All instruments are 5-point, two-way Likert scale (for more metric characteristics of these scales see: Kundačina, 1991; Srbinovski, 2001; and Dunlap et al., 2000).

In the period 1995-2016, a sample of 6387 students from both primary and secondary schools (46 and 86 respectively) were included (Table 2). In general, the sample is intentional, systematic, and stratified. It is intentional because the students were in higher grades, and systematic because we chose each n-th class. Because a range of coincidental moments influenced which students will be found in these classes, the sample is coincidental and representative enough. The sample is also stratified, because the students are on different educational levels, primary and secondary.

\section{Results of the analysis}

During the period under review, seven significant or major studies were conducted. The results are presented as the average score for each study separately. The score ranges from 1-5, with 1 indicating extremely negative attitudes toward the environment, and 5 indicating extremely positive attitudes. Students' level of attitudes towards the environment by years are shown on the Table 3 .

As we can see, average values of the students' environmental attitudes are within the range 2.843.90. The maximum value was recorded at the beginning of the survey period, and the lowest value was obtained during the last survey. The mean of the students' attitudes for the period under review is approximately 3.50 or $70 \%$ which indicates the respondents are characterized by moderately positive attitudes towards the environment.
A number of factors and diverse range of issues were included in the applied instruments. In terms of the instrument applied, we can divide the research period into three sub- periods: sub-period 1995/96-1997/98, when SA-3 was applied; sub-period 1999/2000-2011/12, when SA-6 instrument was applied, and sub-period 2015-2016 when NEP scale was applied. Figure 1 shows the average values of the environmental attitudes by sub-periods.

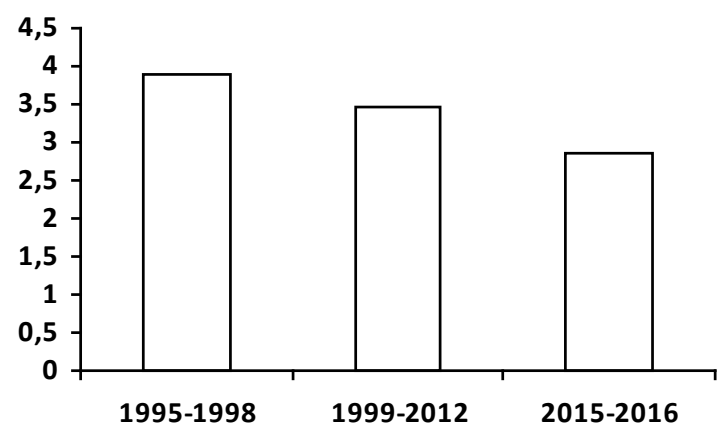

Figure 1. Students' level of environmental attitudes by sub-periods.

The level of students' attitudes towards the environment in the sub-period 1995/96-1997/98, when SA-3 instrument was applied is about 3.89 or $77.80 \%$. The level of students' attitudes toward the environment in second sub-period (1999/2000$2011 / 12$ ), is about 3.47 or $69.40 \%$. This shows that students value highly the balance in the environment, which is a precondition for the survival of all living things, including humans. The majority of the students also consider people/humans to be the most responsible factor of environmental protection. The level of students' attitudes towards the environment in the last sub-period (2015-2016) is approximately 2.84 or $56.80 \%$.

Table 3. Students' attitudes toward the environment ( $n$ ), and differences (d) from mean (3.50).

\begin{tabular}{|c|c|c|c|c|c|c|c|c|c|c|c|c|c|}
\hline \multicolumn{2}{|c|}{$\mathbf{1 9 9 5 / 9 6}$} & \multicolumn{2}{|c|}{$\mathbf{1 9 9 7 / 9 8}$} & \multicolumn{2}{c|}{$\mathbf{1 9 9 9 / 0 0}$} & \multicolumn{2}{c|}{$\mathbf{2 0 0 1 / 0 2}$} & \multicolumn{2}{|c|}{$\mathbf{2 0 0 8 / 0 9}$} & \multicolumn{2}{|c|}{$\mathbf{2 0 1 1 / 1 2}$} & \multicolumn{2}{|c|}{$\mathbf{2 0 1 5 / 1 6}$} \\
\hline $\mathrm{n}$ & $\mathrm{d}$ & $\mathrm{n}$ & $\mathrm{d}$ & $\mathrm{n}$ & $\mathrm{d}$ & $\mathrm{n}$ & $\mathrm{d}$ & $\mathrm{n}$ & $\mathrm{d}$ & $\mathrm{n}$ & $\mathrm{d}$ & $\mathrm{n}$ & $\mathrm{d}$ \\
\hline 3.90 & 0.40 & 3.87 & 0.37 & 3.86 & 0.36 & 3.19 & -0.31 & 3.39 & -0.11 & 3.45 & -0.05 & 2.84 & -0.66 \\
\hline
\end{tabular}




\section{Data analysis in the context of social-economic conditions in the Republic of North Macedonia}

The highest level of the students' attitudes towards the environment was achieved in the first sub-period 1995/96-1997/98, but the lowest in the last sub-period. In general, the results indicate that North Macedonian students consider the environment important. Compared with other countries such as the United Kingdom (3.31-Pahl et al., 2005), the United States (3.57-Kortenkamp and Moore 2006), Australia (3.96-Blaikie 1992), Turkey (3.50-Erdog an 2009), and Brazil (3.55Schultz et al., 2005, cit. in Ogunbode, 2013, p. 1486), the findings of this study suggest that the respondents are characterized by moderately positive attitudes towards the environment. Van Petegem P. and Blieck A. (2006); Boeve-DePauw J. and Van Petegem P. (2012) investigated in their research the views of young people in Belgium, Vietnam and Zimbabwe, using the revised NEP scale. Belgian children are more favored or pro-rated by the NEP (NEP score of $63.18 \%$ ) than children in Zimbabwe (the NEP average score of $51.44 \%)$ and Vietnam - (58.9\%), indicating that Belgian children display more proecological concepts than children in Zimbabwe and Vietnam. Almost all Europeans (95\%) say that protecting the environment is important to them personally, and there is a continuing broadly-felt and strong consensus on the importance of environmental protection in the European Union (European Commission, 2014). Pro-ecological concepts were also observed among students from other countries, e.g. India (Ponmozhi and Krishnakumari, 2017), France (Le Hebel et al., 2014), Bulgaria (Bostrom et al., 2006), Greece (Ntanos et al., 2019), etc.

The results of this research will be discussed in a more in-depth analysis. Not wanting to speculate, we will focus on the factors that evidently influence students' attitudes toward the environment in the North Macedonian context.

Robottom and Hart (1995) believe that historical, social, and political contexts with- in which individual and group actions take place are the key factors which must be included in this type of research. In other words, we must look at studentsattitudes in the context of the overall socialeconomic conditions in which we carry out the educational process. Effective environmental education is based on these pre-conditions: understanding, social safety, economic development, political ideology, and democracy.

Some research has shown that understanding is the key problem. Namely, the people of our region are not conscious enough of the damage to the environment which can be caused by uncontrolled economic development. "Some analyses show that the concept of sustainable development is probably understood only by $10 \%$ of the population in the region. This is not enough for achieving a "critical mass" of actively involved citizens" (Srbinovski et al, 2010: 374).

If we exclude the results of the last measurement, the lowest results are observed in 2000/2001. In this period (2001), there was a military conflict in this area. All of us know the effects of military conflicts. During the military actions, and some time after that, the lessons in some schools lasted only 20 minutes. Working in inadequate rooms and even in schools intended for students of other educational levels was common. For example, secondary school students studied in schools intended for students of primary schools. Of course, the military operations made a deep and stressful impression on the emotional lives of the people. Teachers and students were not spared from all this. In such circumstances, few are able to think about the protection and care of the environment. Consequently, environmental education was on the margins.

Another focal point in the research of environmental attitudes is the influence of the social background or socio-economic status. The degree of development of a community might be positively correlated to pro-ecological conceptions. Research has illustrated that higher income levels are associ- 
ated with higher levels of environmentalism (Shen and Saijo, 2007). In the period 2001/02 our country was faced with a relatively high level of poverty because of an insufficient economic development and the rise of unemployment (Government of the Republic of Macedonia, 2002: 17). Poverty significantly influences the overall situation, both within educational institutions, and outside of them. Poverty has a negative impact both on teachers' motivation for the implementation of environmental contents (Srbinovski, 2004c) and on material circumstances in schools.

Much of the research on environmental attitudes at the individual level focuses on the role of socio-demographics in explaining the differences between the individuals' environmental attitudes. Researchers have demonstrated that younger people tend to hold more environmentally positive attitudes than older people (e.g., Arcury et al., 1987). In this respect, we can emphasize that the mean of students' attitudes in 2001/2002 (when elementary school students were involved) was 3.19 and in 2011/12 (when elementary school students were not involved) it was 3.45 . So we would not place this conclusion in the context of age, because, in our opinion, the obtained data do not support it. Although the link between age and environmental attitudes has been suggested by various scholars, there are inconsistencies in the survey results to support their hypotheses. For instance, the result of the Furman A. survey (1998) showed only a weak relationship between environmental attitudes and age.

\section{Data analysis in the context of formal education in the Republic of North Macedonia}

Schools play an important role in the promotion of positive attitudes towards the environment in young children. The results revealed that "schools with strong orientation towards environmental studies seem to transmit environmental information more effectively than schools with no environ- mental policies" (Barraza \& Walford, 2002: 171). We will analyze some of the most important school factors: curricula, didactic materials-textbooks, environmental knowledge, and teaching process.

Formal environmental education is provided worldwide either as a compulsory subject, as a part of a compulsory subject area, or as an interdisciplinary topic. In the most developed countries there is an attempt to attain consistent achievement of the aims and principles of environmental education. "The key prerequisite for a successful integration of the goals of education for sustainable development and objectives in every school subject curriculum is that these goals and objectives are adapted to suit the characteristics of a particular subject and the specificities of the children's age" (Veinović, 2017: 207). In our country, environmental education is not consistently treated, either as a separate subject or as a principle (Srbinovski, 2001, 2002/2003, 2003a, 2003b, 2003d, and 2005a, Srbinovski et al., 2007, Srbinovski et al., 2010a, and 2010b; Srbinovski \& Palmer, 2008).

The inclusion of environmental issues in the textbooks of the schools is "left to chance" and lacking in appropriate planning for consistency and theoretical grounding (Srbinovski, 2001, 2002, 2003c, 2005a, 2012, 2013a, and 2013b; Srbinovski \& Palmer, 2008). Environmental topics are not widely integrated into formal education courses, they are not connected enough with the problem of environmental protection, and addressing environmental issues is not progressively developed through time in the North Macedonian school system. The analysis of the content of the didactic materials showed that little time (3.04\% in 2001, and $2.18 \%$ in 2012) is spent on ecology in our schools (Srbinovski, 2013b). The environment is mainly treated through its natural aspect. This is in contradiction with one of the primary aims of the environmental education: to enable human beings to understand the complex nature of the environment, as this results from the interaction of its biological, physical, social, eco- 
nomic and cultural aspects. "The fundamental aim of environmental education must be to promote the experience of, and understanding of, what is truly environing: the character of our emplacement... Only in this open receptive-responsive mode- previously characterized as a "loving allowance"- can we become properly aware of the truth of our environmental situation and the proper sources of reference in assessing it and responding to it" (Bonnett, 2016:11). "Considering the fact that the world and the environment are still interpreted with reduction, divided into subjects and the chosen phenomena, there is a question of whether environmental education, in the sense of sustainability and sustainable development, can put in the centre of its intentions a network of life and content which are focused on a stronger knowledge networking" (Andevski, 2016: 31).

Apart from socio-demographics, there are also other factors that affect environmental attitudes, such as the knowledge about the environment (e.g., Schahn and Holzer 1990). Many findings suggest that increased knowledge may help to improve environmental attitudes (e.g. McVittie \& Chamberlain, 2000; Bradley et al. 1999; Ramsey and Rickson, 1984, in McVittie \& Chamberlain, 2000; and Iozzi, 1984). In others words, if a man knows more, he appreciates the environment more. A statistically significant correlation (.35 and .37) between knowledge and attitudes in Macedonian context was reported by Srbinovski, M. (2005b), and Kundačina, M. (1991) respectively. The results of the Third International Mathematics and Science Study (TIMSS) confirm a relatively low level of student knowledge. TIMMS (1999) was designed to show the trends in the eighth-grade mathematics and science achievement in an international context (38 countries). Macedonian students had a significantly higher average only compared to students in Morocco, the Philippines and South Africa (The International Study Center and The International Association for the Evaluation of Educational Achievement, 2000). According to The Program for International
Student Assessment (PISA), a worldwide study by the OECD in 70 nations, we were on the 67th place in science (Organization for Economic Cooperation and Development- OECD, 2015-2016).

There is an increased positive effect on children's attitude when they are taught about the environment in an outdoor/hands-on setting versus an indoor traditional classroom setting. The results showed a positive correlation in children's attitude when taught in an outdoor setting (Khawaja, 2003; Ryan, 1991) or specialized classrooms (Srbinovski, 2004a). Unfortunately, our schools take an old-fashioned approach to developing students' attitudes and values. Biology teaching as a key factor of environmental education in our country also faces these challenges (Srbinovski, 2004b). Without respecting students' different characteristics, needs and interests in accordance with the requirements and conditions of contemporary living, we cannot comprehensively accomplish the goals of environmental education. In the absence of laboratories and specialized classrooms, the teaching process is mainly carried out in traditional classrooms (Srbinovski, 2004a). In these conditions, verbal-illustrative methods and lecture style are dominant. Environmental education cannot be complete without developing love for the environment. This is possible only with direct experience of its values, which will invoke the feelings of satisfaction, inspiration, love, pride, and fear for our own safety. The experiences of the real environment are stronger than any kind of abstract knowledge acquired during lessons or from the textbook. Students must have direct experiences of the environment and develop a feeling of being members/ participants in it. "Environmental education programmes seek to encourage pupils to look at their surroundings and their own place within them with a more practised eye, a more involved heart, and a more responsible mind" (Wolsk, 1977: 47). In this direction, active learning is the most appropriate approach for environmental education and more effective than traditional methods. Studies have shown that whilst you are likely to remem- 
ber only $20 \%$ of what you hear, if you are involved actively through talking and doing, you remember 90\% (Elena \& Zayas, 1977/78, cit. in: Deri and Cooper, 1993: 5). "Those involved in the reform process see the potential value of environmenal education methodologies that incorporate problem-solving, hands-on learning approaches, scientific method, complex thinking strategies, co-operative learning, relevant subject matter and topics that engage students in the educational process" (Hoody, 1995: 14). "We strongly believe that teaching environmental topics requires both integrative and interdisciplinary approaches, active learning methods, outdoor lessons, encouragement of students to explore and analyze, discuss problems, exchange views and observe specific problems from different perspectives" (Stanišić, 2016: 97). The goals connected with the education "about" the environment dominate in the new curricula in the Republic of North Macedonia (93\%). On the other hand, there are very few goals regarding the education "in/from" (2\%) and education "for" (5\%) the environment (Srbinovski et al., 2007). Too often we have concentrated on learning about the environment and put too little emphasis on learning in and for the environment.

The above-mentioned disadvantages of our education system were and still are the cause of many education reforms which have been implemented in the last years. The purpose of the reforms has been to overcome these weaknesses in our schools. The results of the next studies will show to what extent this intention will be accomplished in practice. It is important to point out that the results of some research (Srbinovski, 2004c and 2004d) show that most of our students and teachers are motivated and interested enough to learn and teach environmental content. This can serve as a stimulus to competent institutions to strengthen formal environmental education in our country.

\section{Conclusion}

Most of the participants reported pro-environmental attitudes $(3.50$ or $70 \%)$. The results generally support the hypotheses. We must look at students' environmental education achievements in the context of the overall social-economic conditions in which we carry out the education process. Only after understanding the relationships between the attitudes that people have towards the environment and the factors that influence these attitudes, will we be able to propose a way of teaching that could have a chance of improving the students' attitudes that move towards the development of a sustainable society. Among the factors that influence students' attitudes toward the environment in the North Macedonian context are social-economic conditions (understanding, social safety, economic development) and formal education (curricula, didactic materialstextbooks, environmental knowledge, and teaching process). Since people's environmental attitudes change very slowly, environmental attitudes should be created in the young minds of pupils during the earlier years of education, and as soon as possible.

It is important to note the limitations of this investigation. First, the sample is intentional, systematic, and stratified. This is a limit of the study because the specific sample doesn't allow a large generalisation of the results. Second, the complexity of the problem requires more complex statistical procedures. In our country there are no objectively determined criteria by which we could more accurately and reliably evaluate the results obtained. Third, there are differences among the used scales that can also be the reason for the differences in the results among the sub-periods.

Despite these limitations, these results provide an intriguing insight into students' attitudes over an extended period of time by using different scales. Next, we offer several insights for future research, reflecting upon the limitations of the current study. This research could be used by the environ- 
mental education community in building a more effective dialogue with the education community. In further research it would be interesting to explore other groups and contexts with different educational activities and backgrounds on a large, representative sample. Including other cultural and contextual factors may provide useful information needed to clarify this situation. Further research is needed to clarify the real complexity in the development of students' attitudes toward the environment, includ- ing political preparedness and democracy, by using more sophisticated instruments, e.g. the NEP scale, the revised NEP scale, the 2-MEV scale, the Revised $2-\mathrm{MEV}$ scale, etc. It would be very interesting to analyze the results via a meta-analysis procedure (e.g. Schmidt-Hunters procedure), and to formulate an environmental attitudes model. Developing a model that tries to incorporate all factors might neither be feasible nor useful, but we feel that it can help us to shed more light on this complex field.

\section{References}

- Andevski M. (2016). Sustainable environmental education- Perspective for the change of learning culture, Teaching Innovations, 29 (4), 16-31: 31. DOI: 10.5937/inovacije1604016A

- Barraza Laura and Walford A. Rex (2002). Environmental Education: a comparison between English and Mexican school children. Environmental Education Research. 8 (2), 171-186. DOI: 10.1080/13504620220128239

- Boeve-De Pauw J. and Van Petegem, P. (2012). Cultural Differences in the Environmental Worldview of Children. International Electronic Journal of Environmental Education. 2 (1), 1-11. ISSN: 2146-0329

- Bonnett, M. (2016). Sustainability, nature, and education: a phenomenological exploration. Teaching Innovations, 29 (4), 1-15. DOI: 10.5937/inovacije1604001B.

- Bostrom, Ann; Barke, Richard; Turaga, Rama Mohana R.; O’Connor, Robert E. (2006). Environmental Concerns and the New Environmental Paradigm in Bulgaria, Journal of Environmental Education, 37 (3), 25-40. DOI: 10.3200/JOEE.37.3.25-40

- Bruce Johnson and Manoli C. (2011). The 2-MEV Scale in the United States: A Measure of Children's Environmental Attitudes Based on the Theory of Ecological Attitude. Journal of Environmental Education, 42 (2), 84-97. DOI: 10.1080/00958964.2010.503716

- Burn, M. Sh., Winter, L. P., Hori, B. \& Silver, N. C. (2012). Gender, Ethnic Identity, and Environmental Concern in Asian Americans and European Americans. Human Ecology Review. 19, 2. Retrieved September 10, 2019 from www: http://www.fs.fed.us/psw/publications/ winter/ psw_2012_winter001_burn.pdf.

- Deri A. and G. Cooper (1993). Environmental Education an active approach, A report of Workshops in Kecskemet (1991/1992): 7-9. Tamasi, Pecs, Rychory, Prague, Brno and Bratislava. Budapest.

- Dunlap, R. E., Van Liere, K. D., Mertig, A. G. \& Jones R. E. (2000). Measuring the endorsement of the New Ecological Paradigm: a revised NEP scale. Journal of Social Issues 56(3), 425-442. DOI: 10.1111/00224537.00176

- Eagles, P. F. J., \& Demare, R. (1999). Factors influencing children's environmental attitudes. Journal of Environmental Education, 30 (4), 33-37. DOI: 10.1080/00958969909601882

- European Commission (2008). Attitudes of European citizens towards the environment. Special Eurobarometar 295. Retrieved September 10, 2019 from http://www.socioilogico.com/Attitudes_Europeans_MD_2007. pdf. 
- European Commission (2014). Attitudes of European citizens towards the environment. Special Eurobarometer 416. Retrieved September 10, 2019 from https://ec.europa.eu/commfrontoffice/publicopinion/archives/ ebs/ebs_416_en.pdf.

- Furman, A. (1998). A note on environmental concern in a developing country: results from an Istanbul Survey", Environment and Behaviour, 30 (4), 520-534.

- Government of the Republic of Macedonia (2002). National Assessment Report on Sustainable Development, p. 17

- Hines, J. M., Hungerford, H. R., \& Tomera, N. T. (1986): Analysis and synthesis of research on responsible environmental behavior: A meta- analysis. Journal of Environmental Education, 18 (2), 1-8. DOI: 10.1080/00958964.1987.9943482

- Hoody, L. (1995): The Educational Efficacy of Environmental education, State Education \& Environment Roundtable: 4, San Diego.

- Idrizi, A.; Srbinovski, M. \& Jonuzi, I. (2014). Attitudes of Macedonian High School Students towards the Environment, Procedia- Social and Behavioral Sciences 159, 636 - 642. DOI: 10.1016/j.sbspro.2014.12.439

- Iozzi, L. A. (1984): Summary of research in environmental education, 1971-1982. Columbus, OH: ERIC Clearinghouse for Science, Mathematics, and Environmental Education, Ohio State University. ERIC/SMEAC

- Iozzi, L. (1989): What research says to the educator. Part one and two: Environmental education and the affective domain, Journal of Environmental education, 20 (3, 4), 3-13. DOI:

- 00958964.1989 .9942782

- Johnson, B. \& Manoli, C. (2011). The 2-MEV Scale in the Unites States: A measure of Children's Environmental Attitudes Based on the Theory of Ecological Attitude. The Journal of Environmental Education. 42 (2), 84-97. DOI: 10.1080/00958964.2010.503716

- Jonuzi I. (2009). Environmental education of secondary school students in the Republic of Macedonia (master's work). Tetovo: Communiocation sciences and technologies, SEE University - Tetovo

- Jonuzi, I. (2012). Educational System in functions on promotion of the environment and sustainable developmen (Doctoral dissertation). Skopje: Mit University Skopje

- Khawaja, Amir (2003). Measuring the Environmental Attitudes of Children in Grade 4: A Study in Clark County (Doctoral Dissertations). Las Vegas: University of Nevada. Retrieved September 10, 2019 from https:// digitalscholarship.unlv .edu/thesesdissertations/181.

- Kraus, S. J. (1995). Attitudes and the prediction of behavior: A meta-analysis of the empirical literature. Personality and Social Psychology Bulletin. 21, 58-75. DOI: 10.1177/0146167295211007

- Kundačina, M. (1991): Factors in enabling students to participate in environmental protection (Doctoral dissertation). Skopje: Faculty of Philosophy in Skopje.

- Le Hebel, F., Montpied M. \& Fontanieu V. (2014). What Can Influence Students' Environmental Attitudes? Results from a Study of 15-year-old Students in France, International Journal of Environmental \& Science Education, 9, 329-345. DOI: 10.12973/ijese.2014.218a.

- Manoli, C. Constantinos, Johnson Bruce, Buxner Sanlyn, and Franz Bogner (2019). Masuring Environmental Perceptions Grounded on Different Theoretical Models: The 2-Major Environmental Values (2-MEV) 
Model in Comparison with the New Ecological Paradigm (NEP) Scale. Sustainability 11(5): 1286-, Retrived November 162019 from https://www.researchgate.net/publication/331493264. DOI: 10.3390/su11051286.

- McVittie, E. \& Chamberlain, L. (2000): Implementing an EE program in a high school, EDU 555 - Curriculum Project: 2-4, Retrieved September 10, 2019 from http://www.oswego.edu/ shindler/environed.htm.

- Milfont, T. L. \& Duckitt, J. (2010). The environmental attitudes inventory: A valid and reliable measure to assess the structure of environmental attitudes. Journal of Environmental Psychology. 30 (1), 80-94. DOI: 10.1016/j.jenvp.2009.09.001

- Ntanos S., Kyriakopoulos G., Skordoulis M., Chalikias M. and G. Arabatzis (2019). An Application of the New Environmental Paradigm (NEP) Scale in a Greek Context, Energies, 12. 239, 1-18. DOI: 10.3390/ en 12020239.

- Ogunbode, Charles A. (2013). The NEP scale: measuring ecological attitudes/worldviews in an African context, Environment, Development and Sustainability, 15 (6), 1477-1494. DOI: 10.1007/s10668-013-9446-0.

- Organization for Economic Cooperation and Development- OECD (2015-2016). PISA 2015. Retrieved September 5, 2019 from https://nces.ed.gov/surveys/ pisa/pisa2015/index.asp.

- Organization for Economic Co-operation and Development-OECD and The United Nations Educational, Scientific and Cultural Organization-UNESCO (2001). Teachers for tomorrow's schools, Analysis of the World education educators: 5. Paris. Retrieved September 10, 2019 from http://www.oecd.org/education/ school/teachersfortomorrowsschools.htm.

- Ryan, Chris (1991). The Effect of a Conservation Program on School Children's Attitudes Toward the Environment. The Journal of Environmental Education, 22 (4): 30-35.

- Ponmozhi D. and S. Krishnakumari (2017). Environmental Attitude of School Students. Journal of Humanities and Social Science. 22 (7), 3, 1-4. DOI: 10.9790/0837-2207030104

- Robottom, I. \& Hart, P. (1995): Behaviorist EE Research: Environmentalism as individualism. Journal of Environmental Education, 26 (2), 5-9. DOI: 10.1080/00958964.1995

- Schahn J. and Holzer E. (1990). Studies of individual environmental concern. The role of knowledge, gender, and background variables. Environ Behaviour. 22 (6), 767-786. DOI: 10.1177/0013916590226003

- Schultz, P.W. (2001). The structure of environmental concern: concern for self, other people, and the biosphere. Journal of Environmental Psychology. 21, 327-339. DOI: 10.1006/jevp.2001.0227

- Schultz, P. W., Shriver, C., Tabanico, J.J. \& Khazian, A.M. (2004). Implicit connections with nature. Journal of Environmental Psychology. 24, 31-42. DOI: 10.1016/S0272-4944(03)00022-7

- Shen J, Saijo T (2007) Re-examining the relations between sociodemographic characteristics and individual environmental concern: evidence from Shanghai data. Journal of Environmental Psycholog. 28, 42-50. DOI: 10.1016/j.jenvp.2007.10.003

- Sjoberg Svein \& Camilla Schreiner (2005). How do learners in different cultures relate to science and technology? Asia-Pacific Forum on Science Learning and Teaching. 6 (2), Foreword, p.1. Retrieved September 5, 2019 from http://folk.uio.no/sveinsj/APFLT-foreword-Sjoberg-schreiner.pdf.

- Srbinovski, M. (2001): The environmental education in the primary and secondary schools in the Republic of Macedonia from biological aspect (Doctoral dissertation). Skopje: University "St. Cyril and Methodius", Faculty of Natural Sciences- Institute of Biology Skopje 
- Srbinovski, M. (2002/03). Environmental issues in the curriculum of the upper primary classes. Ekol. Zast. Zivot. Sred. 8 (1-2), 87-98

- Srbinovski, M. (2003a). Comparative aspects of the position of the formal environmental education in our country and in the World. In: Proceedings of the 2nd Congress of Ecologist of the Republic of Macedonia with International Participation (6, 314-320), 25-29.10.2003, Ohrid. Special issues of Macedonian Ecological Society

- Srbinovski, M. (2003b). Environmental issues in the curriculum of the lower primary schools, In: The contemporary pre-school and primary education - states and perspectives (375-386). Scientific meeting with International Participation, Pedagogical faculty, Skopje

- Srbinovski, M. (2003c). Environmental issues in the didactic material of the primary and secondary schools in Republic of Macedonia. Ekologija. 38 (1-2), 41-54

- Srbinovski, M. (2003d). Environmental issues in the secondary (gymnasium) schools curriculum. Prosvetno Delo. 2, 104-115.

- Srbinovski, M. (2004a). Objects of biology teaching and students' environmental education, Vaspitanje $i$ obrazovanje, 3, 40-53

- Srbinovski, M. (2004b). What is environmental education, Prosvetno delo 5, 65-77

- Srbinovski, M. (2004c). Students' motivation for teaching environmental contents, Prosvetno Delo, 1, 69-76

- Srbinovski, M. (2004d). The teacher as a factor of the environmental education in the Macedonian schools. In: Atanasova Vukova A., Ignatovski D. and Toceva J. (ed.). Education and experience (2, 71-76). University "Bishop Konstantin Preslavski", Shoumen.

- Srbinovski, M. (2005a). Environmental Educatio. Skopje: Prosvetno Delo.

- Srbinovski, M. (2005b). The relationships between some cognitive and affective environmental educational areas. SEEU (South-East European University) Review. 2 (2), 223-239

- Srbinovski, M., Palmer, J., Ismaili, M. \& Abazi, A. (2007). Environmental Education in High Schools: an Analysis of New Curriculum Content. In: Starrett S., Hong J., Wilcock R., Li Q., Carson J. And Arnold S. (ed.). Proceedings from the Third International Conference on Environmental Science and Technology (2, 441446), 6-9. 08. 2007. Houston: The American Academy of Sciences.

- Srbinovski, M. \& Palmer, J. (2008). Environmental Education in Macedonian Schools: An Analysis of Curriculum Content and Supporting Materials for Teaching and Learning. Ecology, Biology and Biotechnology. 4, 19-30

- Srbinovski, M., Erdogan, M. \& Ismaili, M. (2010a). Environmental Literacy in the Science Education Curriculum in Macedonia and Turkey, International journal Procedia - Social and Behavioral Sciences, 2, 45284532. DOI: $10.1016 /$ j.sbspro.2010.03.725

- Srbinovski, M., Ismaili, M. \& Abazi, A. (2010b). Environmental education for sustainability across the new Macedonian curriculum. In: Sorial A. and Hong J. (ed.). Proceedings of the 5th International Conference on Environmental Science and Technology (2, 373-380), 12-16.07. 2010. Houston: The American Academy of Sciences.

- Srbinovski, M. (2012). Environmental Contents in the Textbooks of the Primary and Secondary Education in the Republic of Macedonia. In: Da Cunha Martins Costa M.F.P, Vazquez Dorrio J. B., Erdogan M. and Er- 
entay N. (ed.). 9th International Conference on Hands on Science (HSCI'2012) Including 1st Children's Summit on Hands on Science and Environmental Education (250-256), 17-21.10.2012. Antalya: Akdeniz University.

- Srbinovski, M. (2013a). Ecological Issues in the Secondary School Textbooks in the Republic of Macedonia. In: Proceedings of the 4th Congress of Ecologists of Macedonia with International Participation (28, 124-128). 12-15.10.2012. Ohrid: Macedonian Ecological Society.

- Srbinovski, M. (2013b). Environmental Education in Macedonian Schools: A Comparative Analyses of Textbooks. Applied Environmental Education \& Communication. 12 (3), 163-172. DOI: 1533015X.2013.838867

- Srbinovski M. (2016). Gender Differences in Environmentalism: A Case Study of Macedonian Students. Teaching Innovations. (29) 4, 101-114. DOI: 10.5937/inovacije1604101S.

- Stanišić J. (2016). Characteristics of teaching environmental education in primary schools. Teaching innovations, 29 (4), 87-100. DOI: 10.5937/inovacije1604087S.

- The International Study Center \& The International Association for the Evaluation of Educational Achievement (2000). TIMSS 1999 - International Science report. Retrieved 12.08. 2019. from https://timssandpirls. bc.edu > sciencebench_report>t99bscienceA.

- Van Petegem, P. \& Blieck, A. (2006). The environmental worldview of children: a cross-cultural perspective. Environmental Education Research, 12 (5), 625-635. DOI: 10.1080/13504620601053662

- Veinović, Z. (2017). The curricula revision in the context of education for sustainable development: from the perspective of two primary school subjects' curricula. Зборник Института за педагошка истраживања, 49 (2), 191-212, 207. DOI: https://doi.org/10.2298/ZIPI1702191V

- Wiseman, M. \& Bogner, F.X. (2003). A higher-order model of ecological values and its relationship to personality. Personality and Individual Differences, 34, 783-794. DOI: 10.1016/S0191-8869(02)00071-5

- Wolsk, D. (1977): Methodologes of environmental education. In: Trends in environmental education,: 35-48, 47. Paris: UNESCO. 


\section{Миле С. Србиновски}

Универзитет Југоисточна Европа, Институт за животну средину и здравље,

Тетово, Република Северна Македонија

\section{СТАВОВИ МАКЕДОНСКИХ УЧЕНИКА О ЗАШТИТИ ЧОВЕКОВЕ СРЕДИНЕ У ПЕРИОДУ ОД 1995. ДО 2016. ГОДИНЕ}

Постиоје gва разлоїа за йовећане квалийейа живойне среgине у Рейублици Северној Макеgонији: (а) наша држава суочава се са великим изазовима у областии зашитиие и

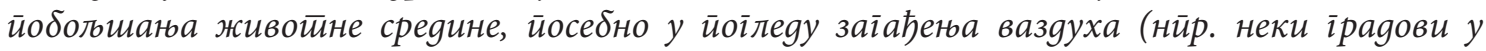

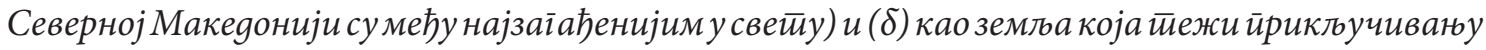
Евройској унији, националне инсиичйуиије имају обавезу gа исйунавају критиеријуме ЕУ $у$

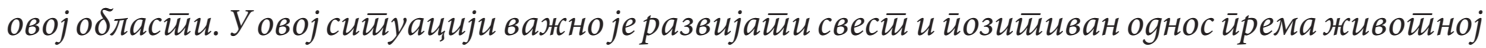
среgини као ӥреgиктиорима еколочкої йонашань.

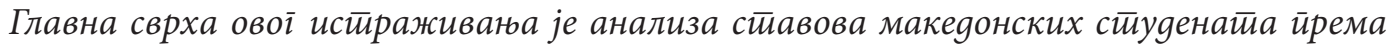

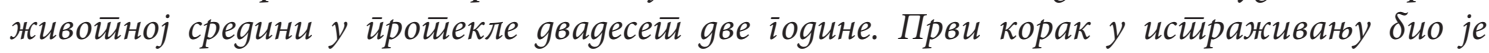
формулисаюе ояређених јасних, неgвосмислених и сирукииурираних йитиаюа. Друіи корак

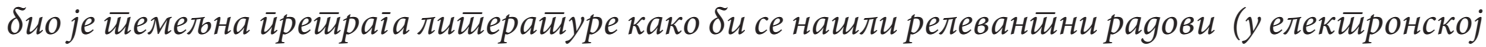
форми и шимамйани) без језичких оіраниченьа. Трећи корак је ирочена квалийейа истираживань. Слеgећи корак йоgразумевао је резимиране доказа или синйезу йоgайака.

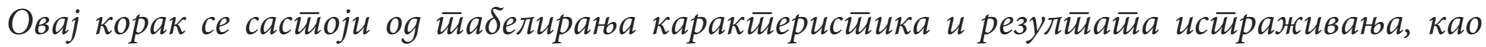

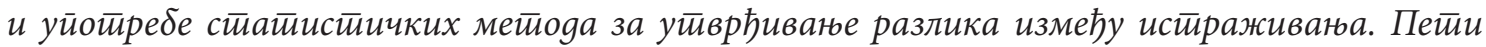

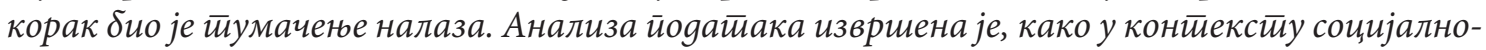

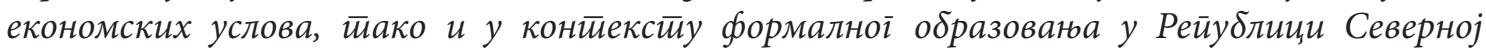
Макеgонији.

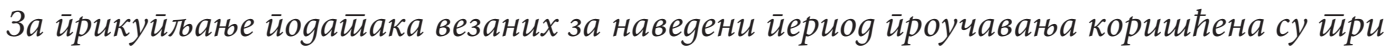

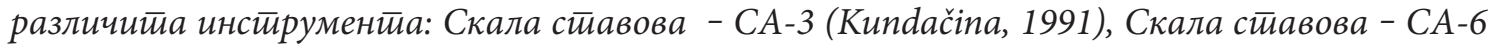
(Srbinovski, 2001) и Нова скала еколошке йараgиіме - скала НЕП (Dunlap et al., 2000). Уктучен

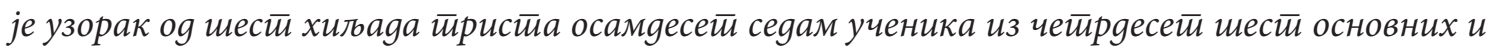
осамgесети шести среgних школа.

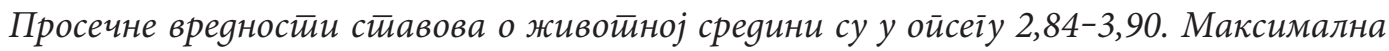

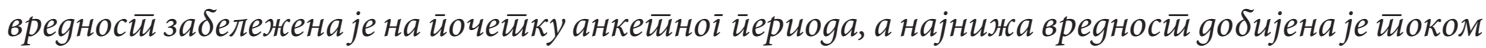

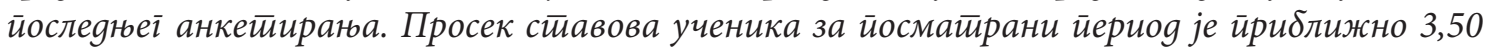
или 70\%, ийо указује gа су исиичйаници имали умерено йозитииван сйав иррема окружену.

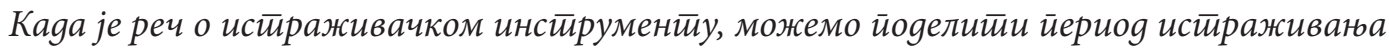

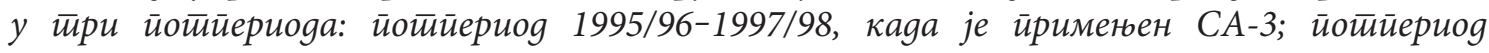
1999/2000-2011/12, каgа је ирименен инсиируменй СА-6, и йоййериоg 2015-2016, каgа је

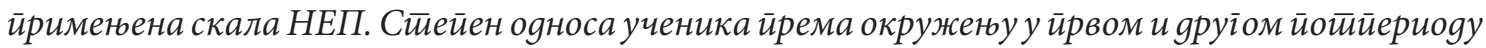
је око 3,89 или 77,80\%, о оносно 3,47 или 69,40\%. То йоказује gа ученици високо иенеравнойежуу

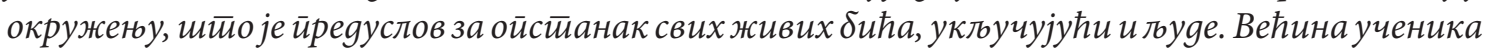

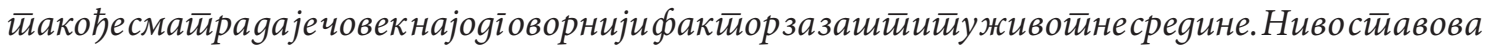


ученика иррема окружену у йослеgюем йоййериоgу (2015-2016) йриближно је 2,84 или 56,80\%.

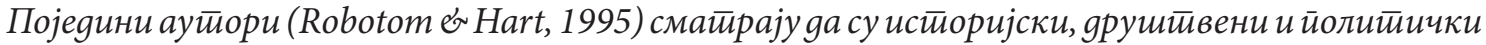

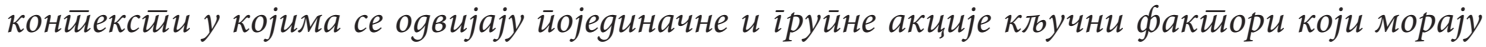
битии укључени у ову врстиу истираживана.

Међу факиторима који уйичу на сииав ученика йрема окружену у македонском

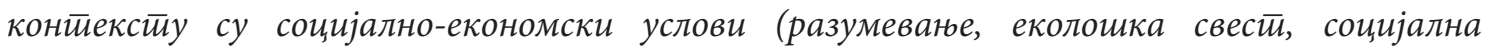

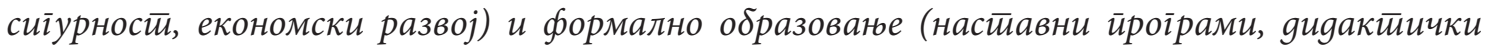

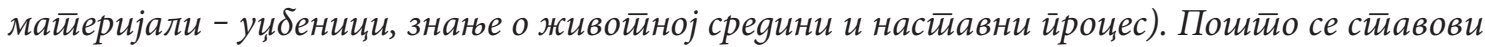
тууяи иррема живоииној среgини менају веома сйоро, у млаgим умовима ученика итребало би креиратии стиявове о живойној среgини већ у нижим разреgима основне школе, шито је ире моїyћe.

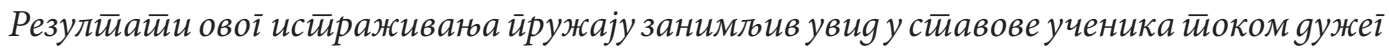

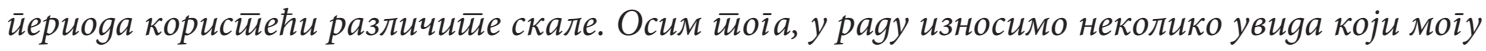

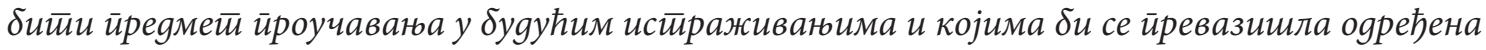

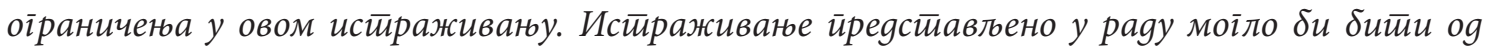

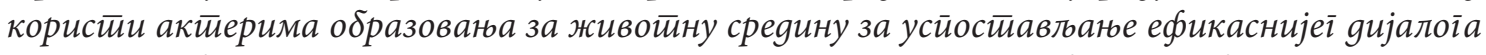
са широм образовном зајеgницом. Дата истираживаға су йойребна како би се разјаснила реална комйлексности у развоју сииавова ученика иррема живойној среgини, уклучујући и gруіе

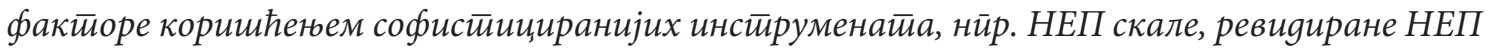
скале, 2-МЕВ скале, ревияиране 2-МЕВ скале ийg. Било би врло занимливо анализирати

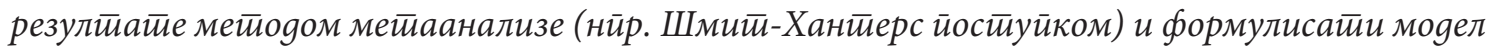

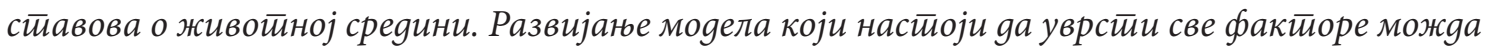

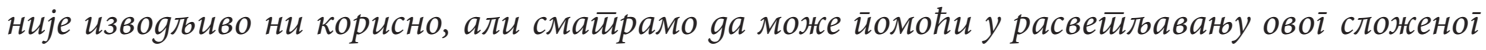
$\bar{u} о љ а$.

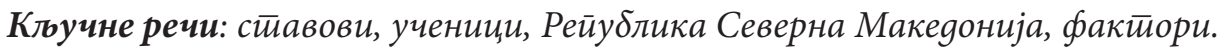

